\title{
Genetic Diversity Analysis of Maize (Zea mays L.) Inbred Lines on the basis of Morphological Traits
}

\author{
Sandeep Kumar Suman ${ }^{1 *}$, Mithilesh Kumar ${ }^{1}$, Ajay Kumar ${ }^{2}$ and Rajesh Kumar ${ }^{2}$ \\ ${ }^{1}$ Department of Agricultural Biotechnology and Molecular Biology, \\ ${ }^{2}$ Department of Plant Breeding and Genetics, Dr. Rajendra Prasad Central Agricultural \\ University, Pusa, Samastipur, Bihar-848125, India \\ *Corresponding author
}

\begin{tabular}{|l|}
\hline Ke y w o r d s \\
$\begin{array}{l}\text { Maize, Inbred lines, } \\
\text { Morphological } \\
\text { traits, Genetic } \\
\text { diversity and } \\
\text { Cluster analysis }\end{array}$ \\
\hline Article Info \\
\hline $\begin{array}{l}\text { Accepted: } \\
24 \text { November } 2018 \\
\text { Available Online: } \\
\text { 10 December } 2018\end{array}$ \\
\hline \hline
\end{tabular}

\section{Introduction}

Maize (Zea mays L.) is the third important cereal crop after wheat and rice and belongs to the tribe Maydeae of the grass family Poaceae. It has a remarkable productive potential among the cereals and has wide economic importance. It shows broad genetic base and wide adaptability, adjust itself globally from temperate to tropical conditions with annual rainfall of 20 to $25 \mathrm{~cm}$, to those where annual rainfall may exceed $400 \mathrm{~cm}$. Maize crop is cultivated from $50^{\circ} \mathrm{N}$ to $40^{\circ} \mathrm{S}$ latitude and at altitude from sea level to 3300 meters. It is highly productive crop among cereals; hence it is called Queen of cereals.

Evaluation of genetic diversity is pre-requisite for identifying promising parents for any hybridization programme in plant breeding. In order to utilize the material for hybrid development, it is imperative to know the 
extent of diversity present among the lines of maize. Most of the modern inbred lines used in maize hybrid programme are second, third or fourth cycle lines which were developed from other inbred lines or from synthetic populations derived from crossing the inbred lines. The genetic diversity can be elucidated by cluster analysis. Cluster analysis is done for organizing data sets so that information can be retrieved more efficiently and can be easily understood without the need for complicated mathematical techniques. It is frequently used to classify maize accessions and can be used by breeders and geneticists to identify subsets of accessions which have potential utility for specific breeding or genetic purposes (Rincon, 1996). The main aim of using a cluster technique for analysis of data from plant breeding trials is to group the inbred lines into several homogeneous groups such that those inbred lines within a group have a similar response pattern. It is reasonable that all the inbred lines in the trials will not behave complete in depend of each other. For instance, those with similar genetic make-up would be expected to behave similarly Jiban (2014). The present investigation was carried out to know the magnitude of diversity present in fifteen inbred lines of maize for morphological and yield components to select diverse parents for its further use in heterotic crosses and wide array of combination.

\section{Materials and Methods}

The experiment was conducted during kharif, 2016 at Tirhut College of Agriculture, Dholi farm of Dr. Rajendra Prasad Central Agricultural University, Pusa, Bihar, with fifteen inbred lines (Table 1) of maize derived from different maize population. The plot had a uniform topography, fertile and well drained soil. The experiment was conducted in Randomized Block Design (RBD) with three replication having plot size of $6.0 \mathrm{~m}^{2}$. Each plot consisted of two rows of $4 \mathrm{~m}$ length each spaced at $75 \mathrm{~cm}$ (row to row) and $25 \mathrm{~cm}$ (plant to plant) respectively. The observations during present investigation were recorded on five competitive plants which were randomly taken from each plot in each replication for recording data of traits. The data were recorded for days of $50 \%$ tasseling, days of $50 \%$ silking, plant height $(\mathrm{cm})$, ear height $(\mathrm{cm})$, tassel length $(\mathrm{cm})$, tassel branch number, cob length $(\mathrm{cm})$, cob girth $(\mathrm{cm})$, number of grains per row, 1000 seed weight (gm). Cluster analysis of morphological data was done on the basis of ward linkage method using MINITAB ver. 18 statistical software.

\section{Results and Discussion}

Analysis of the field data showed that there were highly significant differences for all the ten characters indicating the existence of genetic diversity among the tested inbred lines. On the basis of field data, mean and range were calculated and presented in Table 2. The finding of the field study showed that the tassel branch number had maximum variation (93.27\%) followed by tassel length (24\%) and cob girth (17.52\%). Among the traits, $50 \%$ silking showed lowest variation (4.330\%). Sokolov and Guzhva (1997) also reported significant amount of variability for different morphological trait in maize inbred line populations. The morphological variations were found mainly due to interaction of genetic factors with the environmental factors. The mean value for the characters viz. days of $50 \%$ tasseling, days of $50 \%$ silking, plant height $(\mathrm{cm})$, ear height $(\mathrm{cm})$, tassel length $(\mathrm{cm})$, tassel branch number, cob length $(\mathrm{cm})$, cob girth $(\mathrm{cm})$, number of grains per row, 1000 seed weight (gm) were 55.2, $58.47,179.57,82.93,31.734,8.47,16.67$, $11.66,30.59$ and 235.01 respectively.

The results of the field study (Table 3 ) showed that among the tested inbred lines the maximum days for $50 \%$ tasseling was found 
in line XI (60 days), while it was lowest i.e. 51 days in VI. Previously Rahman (2008) and Shrestha (2016) also reported significant amount of variability for days to tasseling among different maize genotypes. Similarly $50 \%$ silking was highest 63 days in XI and lowest 55 days in VI and XIV. This variability attributed by the inbred lines is due to differential genetic constitution. Previously Shah (2000) and Shrestha (2013) also reported similar results for days of silking traits among maize populations. Plant height ranged from $167 \mathrm{~cm}$ in VI to $195 \mathrm{~cm}$ in IV. This variation is attributed to their genetic background. These results are in conformity with those of Ihsan (2005) who also reported significant amount of variation among different maize populations for morphological traits. Ear height ranged from $99 \mathrm{~cm}$ in IV to lowest $71 \mathrm{~cm}$ in $\mathrm{XV}$. These results are supported by Dijak et al., (1999) who also found significant amount of variability among long and short stature maize populations for ear and plant height. Generally, medium ear height plant is preferred i.e. plant having ear in middle of the plant. The observed variation in the plant height and ear height is due to variability in the genetic makeup of the population. Shrestha (2013) characterized the maize inbreds in Nepal on the basis of agromorphological traits. Abu-alrub (2006) used kernel traits as the best descriptors for classifying Peruvian high-land maize germplasm (Table 4).

Morphological variations were found on the basis of trait under consideration and these fifteen inbred lines of maize were evaluated for divergence and grouped into three major clusters A, B and C. The composition of each cluster is presented in Table 5. Cluster A consisted of 6 inbred lines namely I, III, IV, $\mathrm{V}$, VIII and IX. Cluster B consisted of four inbred lines II, XI, XII and XV and cluster C consisted of five inbred lines namely VI, XIV, X, XIII and VII (Fig. 1).

Table.1 Experimental materials used to analyse morphological diversity

\begin{tabular}{|c|c|c|}
\hline Sl. No. & Pedigree & Codes \\
\hline 1 & CLQRCYQ60-B-B & I \\
\hline 2 & CLQ2540Q-B-B-B-B & II \\
\hline 3 & VL1110240/VL108722-B-14-1-BB & III \\
\hline 4 & 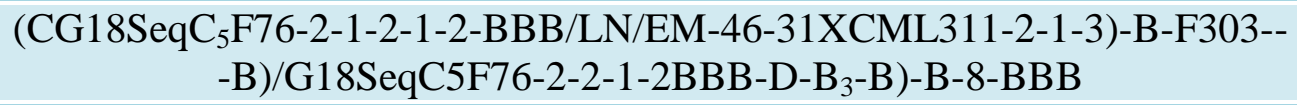 & IV \\
\hline 5 & WNCDMR11R4093 & V \\
\hline 6 & WNCDMR11R6429 & VI \\
\hline 7 & WNCDMR10YFWS8481 & VII \\
\hline 8 & WNCDMR10RYFWS8200 & VIII \\
\hline 9 & CML-490 & IX \\
\hline 10 & HK1-193 & $\mathrm{X}$ \\
\hline 11 & WLS-F ${ }_{2} 8_{7}-1-2-1-B-1-B-B$ & XI \\
\hline 12 & CLQ-RCYQ41 & XII \\
\hline 13 & $\begin{array}{l}\text { G18SEQ.C5F76-2-1-1-1-B/(DT12N,EM-46-3-1XCML311-2-1-3)B-F243- } \\
\text { 1-11(DT/LN/EM-46-3-3-1XCML-311-2-1-3)-B-F243-1-1-B-1-BBB-B }\end{array}$ & XIII \\
\hline 14 & [CML161/CML-165]-BBB-11-BBB/CML193 & XIV \\
\hline 15 & $\left(\right.$ DTPYC $\left._{9}-\mathrm{F}_{46}-3-9-1-2-2-1-3-\mathrm{BBB} / \mathrm{WL}-18-6-2-3-3-1-\mathrm{B}_{5} *\right)-\mathrm{BBB}-1-\mathrm{B}$ & $\mathrm{XV}$ \\
\hline
\end{tabular}


Int.J.Curr.Microbiol.App.Sci (2018) 7(12): 3219-3224

Table.2 Descriptive statistics of average agro-morphological characters of 15 maize inbred lines

\begin{tabular}{|c|c|c|c|c|c|c|c|c|c|c|}
\hline Items & $\begin{array}{c}50 \% \\
\text { tasseling } \\
\text { (Days) }\end{array}$ & $\begin{array}{c}50 \% \\
\text { silking } \\
\text { (Days) }\end{array}$ & $\begin{array}{l}\text { Plant } \\
\text { height } \\
(\mathrm{cm})\end{array}$ & $\begin{array}{c}\text { Ear } \\
\text { height } \\
(\mathrm{cm})\end{array}$ & $\begin{array}{l}\text { Tassel } \\
\text { length } \\
(\mathrm{cm})\end{array}$ & $\begin{array}{c}\text { Tassel } \\
\text { branch } \\
\text { (number) }\end{array}$ & $\begin{array}{c}\text { Cob } \\
\text { length } \\
(\mathrm{cm})\end{array}$ & $\begin{array}{l}\text { Cob } \\
\text { girth } \\
(\mathbf{c m})\end{array}$ & $\begin{array}{c}\text { Grains } \\
\text { per row } \\
\text { (Number) }\end{array}$ & $\begin{array}{c}1000 \\
\text { seed } \\
\text { weight } \\
(\mathrm{gm})\end{array}$ \\
\hline Mean & 55.2 & 58.47 & 179.57 & 82.93 & 31.734 & 8.47 & 16.67 & 11.66 & 30.59 & 235.01 \\
\hline $\mathrm{SE}( \pm)$ & 0.663 & 0.654 & 2.373 & 1.446 & 1.98 & 2.04 & 0.646 & 0.527 & 0.53 & 7.23 \\
\hline $\operatorname{SD}( \pm)$ & 2.57 & 2.532 & 9.19 & 5.602 & 7.65 & 2.81 & 2.501 & 2.043 & 2.602 & 28.02 \\
\hline CV(\%) & 4.65 & 4.330 & 5.12 & 6.75 & 24 & 93.27 & 15.0 & 17.52 & 8.42 & 11.923 \\
\hline Range & 9 & 8 & 28 & 20 & 25.17 & 8.66 & 10.1 & 6.40 & 9.3 & 83.41 \\
\hline
\end{tabular}

SE: Standard error, SD: Standard deviation, CV: Coefficient of variation

Table.3 Characters along with their mean data of morphological traits of 15 inbred lines

\begin{tabular}{|c|c|c|c|c|c|c|c|c|c|c|}
\hline $\mathrm{z}$ & $\begin{array}{c}50 \% \\
\text { tasseling } \\
\text { (Days) }\end{array}$ & $\begin{array}{l}\mathbf{5 0 \%} \\
\text { silking } \\
\text { (Days) }\end{array}$ & $\begin{array}{l}\text { Plant } \\
\text { height } \\
(\mathrm{cm})\end{array}$ & $\begin{array}{c}\text { Ear } \\
\text { height } \\
(\mathrm{cm})\end{array}$ & $\begin{array}{l}\text { Tassel } \\
\text { length } \\
(\mathrm{cm})\end{array}$ & $\begin{array}{c}\text { Tassel } \\
\text { branch } \\
\text { (number) }\end{array}$ & $\begin{array}{l}\text { Cob } \\
\text { length } \\
(\mathrm{cm})\end{array}$ & $\begin{array}{l}\text { Cob } \\
\text { girth } \\
(\mathrm{cm})\end{array}$ & $\begin{array}{c}\text { Grains } \\
\text { per row } \\
\text { (Number) }\end{array}$ & $\begin{array}{c}1000 \\
\text { seed } \\
\text { weight } \\
(\mathrm{gm})\end{array}$ \\
\hline I & 56 & 59 & 177.5 & 87.5 & 27.33 & 9.33 & 15.7 & 11.6 & 28.14 & 222.51 \\
\hline II & 57 & 60 & 187 & 87 & 17.83 & 6.33 & 17.7 & 14.45 & 31.5 & 274.28 \\
\hline III & 54 & 57 & 180 & 83 & 23.33 & 8 & 16.95 & 9.8 & 29.9 & 228.35 \\
\hline IV & 55 & 59 & 195 & 91 & 28.17 & 4.67 & 15.4 & 12 & 29.03 & 228.5 \\
\hline V & 53 & 57 & 188.5 & 85 & 24.17 & 7 & 16.6 & 11.15 & 29.42 & 243.93 \\
\hline VI & 51 & 55 & 167 & 84.5 & 37.17 & 6 & 14.5 & 11.9 & 30.11 & 202.82 \\
\hline VII & 54 & 57 & 189.5 & 72.5 & 24.83 & 6.33 & 9.9 & 11.1 & 27.1 & 198.3 \\
\hline VIII & 56 & 60 & 175.5 & 88.5 & 32.17 & 12.33 & 13.75 & 9.3 & 29.63 & 248.02 \\
\hline IX & 53 & 57 & 178.5 & 84.5 & 38.17 & 7.67 & 16.25 & 8.15 & 32.74 & 251.42 \\
\hline $\mathbf{X}$ & 54 & 56 & 167.5 & 80 & 33.5 & 5.33 & 14.5 & 8.75 & 36.4 & 216.56 \\
\hline XI & 60 & 63 & 187.5 & 81 & 43 & 13.33 & 15.9 & 13.6 & 29.98 & 261.63 \\
\hline XII & 56 & 58 & 186 & 81 & 32.17 & 8.33 & 16.25 & 14.1 & 28.32 & 270.25 \\
\hline XIII & 59 & 62 & 167.5 & 80 & 41.67 & 13 & 18.85 & 13.05 & 29.82 & 211.93 \\
\hline XIV & 52 & 55 & 168 & 87.5 & 30 & 8.33 & 19.5 & 11.4 & 30.98 & 191.65 \\
\hline XV & 58 & 62 & 178.5 & 71 & 42.5 & 11.33 & 20 & 14.55 & 35.73 & 275.06 \\
\hline
\end{tabular}

*The name of maize inbred lines were assigned as code no. in mean data table and for their clustering in dendrogram 
Table.4 Agro-morphological traits of 15 inbred lines within and among three clusters

\begin{tabular}{|c|c|c|c|}
\hline Variable & Cluster A & Cluster B & Cluster C \\
\hline Days to 50\% tasseling & 54.500 & 57.750 & 54.000 \\
\hline Days to 50\% Silking & 58.167 & 60.750 & 57.000 \\
\hline Plant height (cm) & 182.500 & 184.750 & 171.900 \\
\hline Ear(height cm) & 86.583 & 80.000 & 80.900 \\
\hline Tassel length (cm) & 28.890 & 33.875 & 33.434 \\
\hline Number of Tassel & 8.167 & 9.830 & 7.798 \\
\hline branch & & & \\
\hline Cob length (cm) & 15.775 & 17.462 & 15.450 \\
\hline Cob girth (cm) & 10.333 & 14.175 & 11.240 \\
\hline Number of grains/row & 29.810 & 31.383 & 30.882 \\
\hline 1000 seed weight (gm) & 237.122 & 270.305 & 204.252 \\
\hline
\end{tabular}

Table.5 Grouping of 15 inbred lines into three clusters based on agro-morphological traits

\begin{tabular}{|c|c|c|}
\hline Cluster & Number of inbred lines & Code of inbred lines \\
\hline A & 6 & I, III, IV, V, VIII, IX \\
\hline B & 4 & II, XI, XII, XV \\
\hline C & 5 & VI, VII, X, XIII, XIV \\
\hline
\end{tabular}

Figure.1 Cluster diagram obtained on the basis of morphological data (algorithm: Ward's method and similarity measure: Euclidean distance) depicting relationship among 15 inbred lines

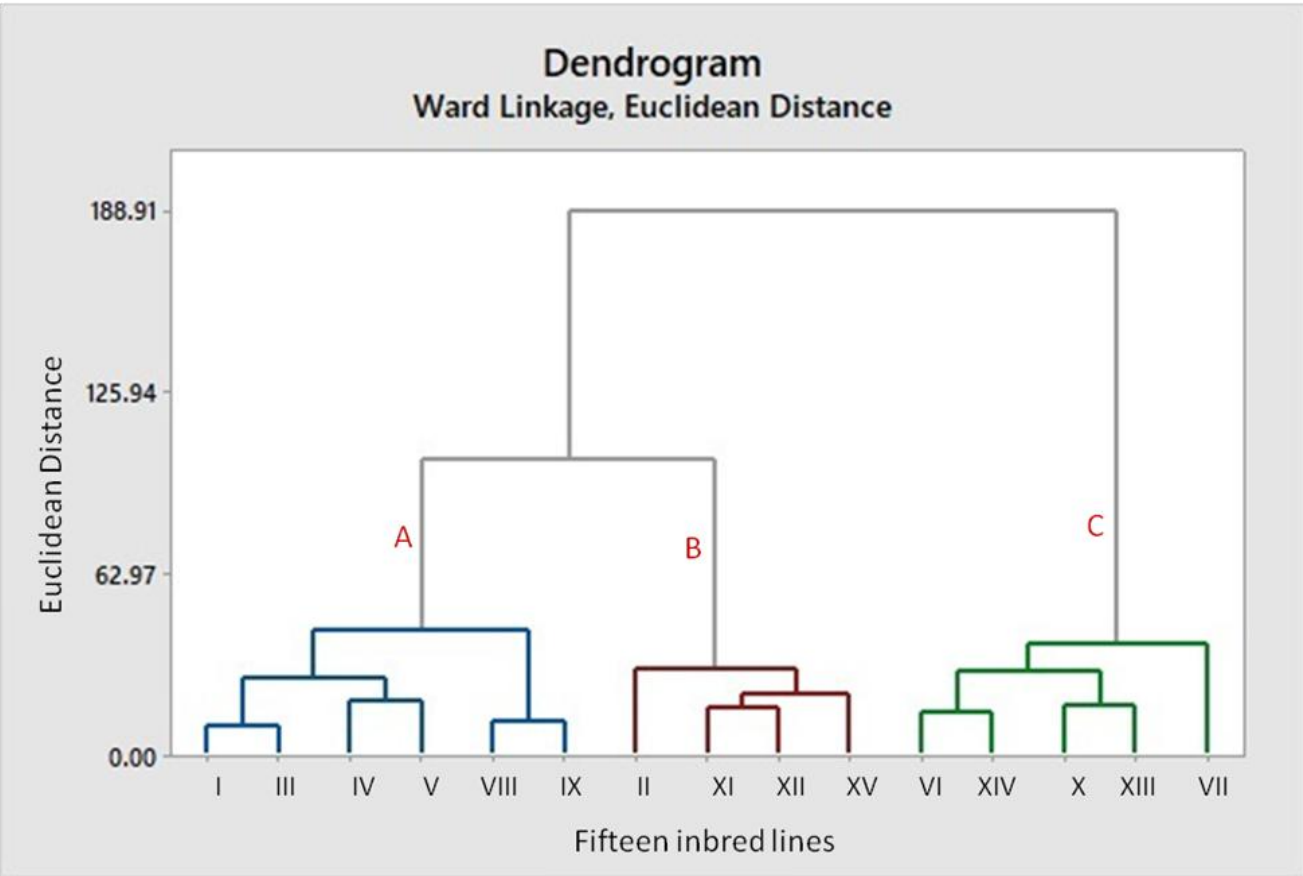


In conclusion the genetic diversity was observed in agromorphological traits namely days to $50 \%$ tasseling, days to $50 \%$ silking, plant height $(\mathrm{cm})$, ear height $(\mathrm{cm})$, tassel length $(\mathrm{cm})$, tassel branch number, cob length $(\mathrm{cm})$, cob girth $(\mathrm{cm})$, number of grains per row, 1000 seed weight (gm) in the tested maize inbred lines. The inbred lines grouped into cluster B had larger tassel length and tassel branch whereas lines in cluster A showed greater variation in anthesis-silking interval, which is a desirable agromorphological trait for out crossing. The presence of high level of diversity among the inbred lines grouped into divergent clusters indicated their suitability for hybridization and breeding program to develop potential hybrid and synthetic varieties.

\section{Acknowledgement}

The authors would like to thank Dr. Ajay Kumar, Maize breeder Department of Plant Breeding and Genetics, Dr. Rajendra Prasad Central Agricultural University, Pusa for providing invaluable advice, cooperation, and providing excellent technical assistance during field trials to data analysis, without his support this study could not have been completed.

\section{References}

Abu-alrub, I., Christiansen, J. L., Madsen, S., Sevilla, R. and Ortiz, R. (2006). Assessing tassel, kernel and ear variation in Peruvian highland maize. Plant Gen. Res. Newsletter.137: $34-$ 41.

Dijak, M., Modarres, A.M., Hamilton, R.I.,
Dwyer, L.M., Stewart, D.W., Mather, D.E. and Smith, D.L. (1999). Leafy reduced-stature maize hybrids for short-season environments. Crop Sci. 39(4): 1106-1110.

Ihsan, H., Khalil, I. H., Rahman, H. and Iqbal, M., (2005). Genotypic Variability for morphological traits among exotic maize hybrids. Sarhad. J. Agric. 21(4): 599-602.

Rahman, H., Ali, S., Shah, S.M.A., Shah, S.S. and Rahman, N., Khalil, I.A., Hussain, I. and Afzal, F. (2008). Diversity for morphological and maturity traits in maize populations from upper dir. Sarhad J. Agric. 24(3): 439-443.

Rincon, F., Johnson, B., Crossa, J. and Taba, S. (1996). Cluster analysis, an approach to sampling variability in maize accessions. Maydica. 41: 307316.

Shah, R.A., B. Ahmed, M. Shafi and Bakht, J. (2000). Maturity studies in hybrid and open pollinated cultivars of maize. Pak. J. Biol. Sci. 3(10): 1624-1626.

Shrestha, J. (2013). Agro-morphological characterization of maize inbred lines. Wudpecker J. of Agri. Res. 2 (7): 209 211.

Shrestha, J. (2014). Morphological variation in maize inbred lines. Int. J. Environment. 3(2): 98-107.

Shrestha, J. (2016). Cluster Analysis of Maize Inbred Lines. J. Nepal Agri. Res. Council. 2: 33-36.

Sokolov, V.M. and Guzhva, D.V. (1997). Use of qualitative traits for genotypic classification of inbred maize lines. Kukuruza I sorgo. 3: 8-12.

\section{How to cite this article:}

Sandeep Kumar Suman, Mithilesh Kumar, Ajay Kumar and Rajesh Kumar. 2018. Genetic Diversity Analysis of Maize (Zea mays L.) Inbred Lines on the basis of Morphological Traits. Int.J.Curr.Microbiol.App.Sci. 7(12): 3219-3224. doi: https://doi.org/10.20546/ijcmas.2018.712.372 